\title{
Effect of Nitrogen Fertilization, Proline, Plant Spacing and Irrigation Intervals on Growth of Maize Plant Sally F. Abo El-Ezz ${ }^{1}$ and Soad H. Haffez ${ }^{2}$ ${ }^{1}$ Soil Dept., Fac. Agric., Mansoura University ${ }^{2}$ Agronomy Dept., Fac. Agric., Mansoura University
}

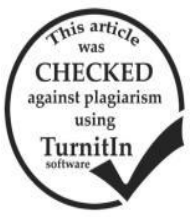

ABSTRACT

The purpose of this research was to study the impact of $\mathrm{N}$ levels applied with proline as well as plant distance on the vegetative growth, chemical content, yield, yield components, and quality attributes of maize under different irrigation intervals. The research was undertaken at an experimental field of Agricultural Faculty, El-Mansoura University during 2018-2019. The results showed that application of $150 \%$ nitrogen fertilization from recommended dose in presence of $50 \mathrm{mg} / \mathrm{l}$ proline significantly increased growth parameters (plant length, fresh and dry weight of flag, leaves area), chlorophyll content, N, P, K and proline content of maize leaves as well as yield attributed (ear length, 1000-graine weight, grain yield and straw yield) and quality of grains (crude proline, fiber, total carbohydrates and oil\%). All parameters under investigation recorded high significant values with plant spacing $15 \mathrm{~cm}$. As for irrigation intervals the results revealed that 11 days' intervals were the most suitable for previous maize parameters. So, it could be recommended touse $150 \mathrm{~N}$-fertilization in presence of proline $+15 \mathrm{~cm}$ plant spacing and 11 days' irrigation intervals.

Keywords: N-fertilization, proline, plant spacing, irrigation intervals and maize plants.

\section{INTRODUCTION}

Maize (Zea mays L.) is considered one of the most remarkable summer cereal crops grown in Egypt used for human consumption and animal feed. It globally rows the third site at cereal crops family after rice and wheat (Gerpacio and Pingali, 2007) and called 'King of cereals'. Rising production of maize became one of the most significant objectives of the Egyptian agricultural policy to confront the human and animal requests. Among various cultivated economically significant cereal crops, maize not just has sufficient content of tocopherols, carotenoids and oil, but additionally has huge amounts of protein and starch contrast with other major food crops such as wheat and rice. In spite of the fact that maize is mainly cultivated for carbohydrate production, in the previous several years, it has incresed great significance as an exporter of vegetable oil for the food industry (Ali et al., 2013). The maize kernel is composed of around $10 \%$ protein, $72 \%$ starch, $2 \%$ sugar, $5 \%$ oil, and $1 \%$ ash with the remainder being water (Shrestha et al., 2018). This could be achieved through following the proper management systems which could lead to maximize its productivity. Optimum controlling water, plant density, fertilizer and chemical inputs is important for ameliorative the growth variables responsible for high yield.

Egyptian soils are known to be poor in available nitrogen due to their low content of organic matter and the low a mounts of organic manures added annually. Corn requests high amounts of $\mathrm{N}$ (Alimohammadi et al., 2011). So, for an optimal yield, the $\mathrm{N}$ supply must be available accessible to the needs of the plant. Nitrogen $(\mathrm{N})$ has the largest effect on the productivity and industrial gain of corn (Carmo et al., 2012). Mekdad (2015) reported that increase in yield due to increasing $\mathrm{N}$-fertilization levels could be due to the importance of $\mathrm{N}$ as one of the macronutrient elements for plant nutrition and its role in improvement vegetative growth during growing leaf initiation, increment chlorophyll concentration in leaves which may reflected in improving photosynthesis process. Number of marketable ears, the length and diameter of the ears, and the productivity of ears and grains effects by the nutritional condition of N in plants the (Carmo et al., 2012). Similarly, Chemical content of maize grains as oil and carbohydrate concentrations are increased significantly by application of
N (Ibrahim and Kandil, 2007) also, increasing the proline content and amino acid formation (Ali et al., 1999). addition of $120 \mathrm{~kg} / \mathrm{fed}$ increased significant plant height, number of leaves/plant, ear leaf area/plant (Bamuaafa, 2012).

Proline is the most common compatible solute that happens in a wide variety of plants. It is considered as the most significant amino acids that collect in different tissues of the plant, especially in the leaves, the gathering of this amino acid has a job in the regulation of osmosis in the cell as the proline is packed in the cytoplasm to counterbalance effort osmosis cell sap. Additionally, proline secures enzymes under stress conditions (Meister 2012). Just as proline is an index for dryness where an increase in the leaf proof that the plant sustained from stress. Likewise, it is one of the manners that the plant show protection from any pressure, the gathering of proline in the leaf appearance is a sort of adaptation with dryness to spare the best content of water in the plant (Tarighaleslami, Zarghami et al., 2012).

Optimum density plant ensures the plants to become appropriately both in their aerial and underground parts through various usage of nutrients and solar radiation. Since it is accepted to have impacts on light interception during which photosynthesis happens, the energy manufacturing medium, utilizing green parts of the plant. Additionally, it influences the rhizosphere exploitation and photosphere by the plants particularly when spacing is inadequate and the plants endures clustering together. Great spacing between plant gives the correct plant density, which is the number of plants, permitted on a given unit of land for optimum yield (Ibeawuchi et al., 2008). Higher plant density than optimum level, resulted in severe rivalry among plants for light over ground or for nutrients underneth the ground, thus the plant development slows down and the grain yield decreases. Tahmasbi and Mohasel (2009) showed that increase plant density significantly increased the growth of grain yield and recorded from 85000 plant/ha with 11.13 t/ha. Saadat et al., (2010) stated that the highest number of grains per ear and number of rows per ear were found from 40000 Plant/ha. Futlless et al., (2010) comparing 4 spacing (75 x 25, 75 x $20,75 \times 15$ and $75 \times 10 \mathrm{~cm}$ ) they found that maize planted at $75 \times 25 \mathrm{~cm}$ confer the highest grain yield of $1900 \mathrm{~kg} / \mathrm{ha}$. So, they recommended that farmers should adopt the spacing of $75 \times 25 \mathrm{~cm}$ for utmost productivity. Boloyi 
(2014) bespoke a spacing of $90 \times 25 \mathrm{~cm}$ for farmers since the highest average yield of $232.3 \mathrm{~kg} / \mathrm{ha}$ came from it comparing with the other spacing of $75 \times 25$ and $75 \times 50$ $\mathrm{cm}$ that produced lower yields.

Water is one of the most bountiful complex on the ground and $2 / 3$ of the ground-level was covered or surrounded with water, but in most part of the world, shortage of water is a factor which is limit the direction of the agricultural products (Reddy et al., 2004). Resources of water in Egypt are constrained and limited crop production in the newly reclaimed lands due to current intensive agricultural production. The agricultural sector consumes more than $84 \%$ of available water resources (El-Beltagy and Abo-Hadeed, 2008). Water shortage in Egypt is considered as a factor which limit the growth and plantation of the agricultural plants. Plants often suffer from water deficiency, and the severity of the resulting damage varies building on the duration and intensity of the stress. Other than the obvious impacts of drought stress, the impacts of water deficit are not surly known at the biochemical and molecular levels. Extending the irrigation intervals for corn crop decreased vegetative growth; grain yield and yield components (Reza and Mehdi, 2002). Grain yield significantly decreased from 8.67 to $6.83 \mathrm{Mg}$ ha61 with corresponding decrease in seasonal cumulative crop evapotranspiration (ETC) from 59.9 to $55.3 \mathrm{~cm}$, daily ETC from 5.25 to $4.86 \mathrm{~mm} \mathrm{day}^{-1}$, WUE from 1.445 to $1.340 \mathrm{~kg}$ $\mathrm{m}^{-3}$ water with increasing irrigation intervals from 10 to 20 days (Sharaan et al., 2002). Growth and yield components were increased with increasing irrigation based on cumulative pan evaporation. The highest $\mathrm{ET}_{\mathrm{C}}(60.32 \mathrm{~cm})$ (El-Tantawy et al., 2007). grain yield significantly reduced by $15.8 \%$, ETC by $10.8 \%$ with increasing irrigation intervals from 7 to 14 or 21 days (Abdel-Maksoud et al.,2008).

So, this is the need of time to develop maize plant management strategy. So, our study was planned to evaluate the effect of levels of $\mathrm{N}$ applications with proline as well as plant distance on the vegetative growth, chemical content, yield, yield components, and quality attributes of maize under different irrigation intervals and to determine the optimum treatments should be used by farmers.

\section{MATERIALS AND METHODS}

The research was build out at an experimental field of Agricultural Faculty, El-Mansoura University during 2018-2019.

The soil hasclay loam texture, alkaline ( $\mathrm{pH} 7.89)$. The soil of the trial site has no salt problem (EC $1.02 \mathrm{dSm}^{-1}$ $(1: 5 \mathrm{w}: \mathrm{v})$ and the organic matter content is low $(1.76 \%)$, $\mathrm{CaCO}_{3} 4.65$, SP 59.5\% and available $\mathrm{N}, \mathrm{P}$ and $\mathrm{K}$ were determined according to Reeuwijk, (2002) which were $56.62,7.11$ and $191.6 \mathrm{mg} . \mathrm{kg}^{-1}$, respectively.

In split-split plot design an experiment was laid out with three replications, in presence and absence of proline with 3 levels of nitrogen fertilization (50, 100 and 150\% from recommended doses) as main plot, 2 different plant distances $(10$ and $15 \mathrm{~cm})$ as sub plot and 3 levels of irrigation intervals (7, 11 and 15 days) as sub-sub plots. Thus, the total number of the experimental plot were 108 plots.
Nitrogen fertilizer was added in the soil as urea at a 3 rate from recommended dose $(120 \mathrm{Kg} \mathrm{N} /$ fed.) in two equal proportions, the $1^{\text {st }}$ half at 30 and the $2^{\text {nd }}$ at 45 days after sowing. Phosphorus fertilizer was added as superphosphate at the rate of $200 \mathrm{Kg} \mathrm{P}_{2} \mathrm{O} 5 /$ fed. before sowing. Potassium as potassium sulfate $\mathrm{K}_{2} \mathrm{SO}_{4}$ was added to the soil before sowing at the rate of $50 \mathrm{Kg} \mathrm{K} \mathrm{K}_{2} \mathrm{O} / \mathrm{fed}$. Plants were sprayed with proline at the rate of $50 \mathrm{mg} / \mathrm{l}$ at two growing stage, 30 and 45 days after sowing with adding nitrogen fertilization.

Two levels of plant density: 30 plant/ridge each consisted of $70 \times 10 \mathrm{~cm}$ and 20 plant/ridge. each consisted of $70 \times 15$ $\mathrm{cm})$. From the third irrigation, the irrigation treatments were started, which included 7, 11 and 20 days' interval. Irrigation surface was adopted to convey the irrigation water to the experimental plots.

The plot area was $10.5 \mathrm{~m}^{2}(3 \times 3.5)$ having 5 ridges of $3 \mathrm{~m}$ in length and $70 \mathrm{~cm}$ in width. Planting date was on $15^{\text {th }}$ of May during growing season. Thinning to one plant per hill was done 30 days after planting.

At full maturity, plants were randomly harvested from each plot to record the following traits:

- Plant length (cm), fresh and dry weight of flag $(\mathrm{g})$, leave area $\left(\mathrm{cm}^{2}\right)$.

- Ear length (cm), 1000-grain weight (g), while, total grain yield (kg/fed.) and straw yield (kg/fed.) were calculated on the plot bases.

* Chemical content of leaves as chlorophyll content (a, b and total chlorophyll), N, P and $\mathrm{K} \%$ as well as proline accumulation were determined according to Gavrilenko and Zigalova (2003), Mertens, (2005), Agrilasa, (2002)and (Marin et al., 2010), respectively.

* Quality of seeds as Carbohydrates \% (Shumaila and Safdar, 2009), fiber and protein according to (AOAC, 2000), and oil\% according to

Using CoSTATE Computer Software and the means of treatments were compared by using LSD test at levels of $5 \%$ probability. The Randomized Complete Blocks design in split plot outlined by Gomez and Gomez (1984), data were statistically analyzed according to the procedures of ANOVA.

\section{RESULTS AND DISCUSSION}

\section{Growth parameters:}

Data at Table 1 showed the effect of individual application with nitrogen fertilization in absence and presence of proline, plant distance and irrigation interval on growth parameters of maize plant.

Results in Table 1showed that $\mathrm{N}$ fertilizer levels and proline significantly influenced plant length, fresh and dry weight of flag, leave area of maize. Growth parameters were the highest at the rate of $150 \% \mathrm{~N}$ from recommended dose in absence of proline ( $50 \mathrm{ppm}$ ) as compared with low application rats. This may be due to the important role of nitrogen in building both of co-enzymes, protein and nuclic acid which reflect to vegetative growth parameters also, the increase in leaf area could possibly be ascribed to the fact that nitrogen increases plant growth and plant height and this resulted in more nodes and internodes, similar results were obtained by (Hafez and Abdelaal 2015; Woldesenbet and Haileyesus 2016 and Ali and Anjum 2017). As for the 
effect of proline this result was agreement with those of (Al-Shaheen and Soh 2016 and Baddour et al., 2017).

In the same Table, the effect of plant distance was illustrated and found that with increase, the growth parameters under investigation was increased, the highest mean values of plant length, fresh and dry weight of flag, leave area of maize recorded with plant spacing at $15 \mathrm{~cm}$. The increase in plant vegetative may be due to competition for light which, might be responsible for increase in height due to closer intra-row spacing and this might have resulted in longer internodes, also, the higher leaf area per plant in the wider inter-row spacing and intra-row spacing might be due to more availability of growth factors and better penetration of light, consequently increased number of leaves produced and the size of individual leaves in plants at wider row spacing. This result was in agreement with (Nand, 2015; Getaneh et al., 2016 and Lihiang and Lumingkewas 2017).
Regarding to the effect of irrigation intervals, the mean values of parameters under study were significantly decreased with increasing irrigation intervals from 7 up to 11 days then decreased at 15 days as in indicate at Table 1 on vegetative growth parameters. Also, the highest values were $223.90,13.49,4.07$ and 676.25 for plant length, fresh and dry weight of flag, leave area of maize, respectively were realized when the plants irrigated at 11 days while, the lowest one was happened when plants irrigated at 15 days. It could be suggested that increasing water quantity applied to plant led to keep higher moisture content in the soil and this in turn might favored the plant metabolism that leads to increase the plant growth characters and to produce higher dry matterthen a reduction in plant height was observed as irrigation interval prolonged this may be due to the fact that water stress produced short plants. The finding of this study is in agreement with the results of Abo-Marzoka et al., 2016; Majid et al., 2017.

Table 1. Individual application of nitrogen fertilization in absence and presence of proline, plant distance and irrigation interval on growth parameters of maize plant.

\begin{tabular}{|c|c|c|c|c|}
\hline \multirow{2}{*}{\multicolumn{5}{|c|}{$\begin{array}{r}\text { Plant length cm } \\
\text { Nitrogen and proline fertilization }\end{array}$}} \\
\hline & & & & \\
\hline $50 \% \mathrm{~N}$ & 187.35 & 12.28 & 3.45 & 570.26 \\
\hline $50 \% \mathrm{~N}+$ proline & 197.53 & 12.37 & 3.57 & 605.88 \\
\hline $100 \% \mathrm{~N}$ & 212.35 & 13.09 & 3.91 & 648.21 \\
\hline $100 \% \mathrm{~N}+$ proline & 225.09 & 14.07 & 4.35 & 677.87 \\
\hline $150 \% \mathrm{~N}$ & 238.54 & 13.33 & 4.02 & 712.58 \\
\hline $150 \% \mathrm{~N}+$ proline & 251.69 & 14.29 & 4.47 & 749.18 \\
\hline LSD at $5 \%$ & 0.69 & 0.11 & 0.03 & 0.95 \\
\hline \multicolumn{5}{|c|}{ Plant distance } \\
\hline $10 \mathrm{~cm}$ & 214.95 & 12.97 & 3.85 & 647.61 \\
\hline $15 \mathrm{~cm}$ & 222.57 & 13.51 & 4.07 & 673.72 \\
\hline LSD at $5 \%$ & 0.28 & 0.03 & 0.01 & 0.32 \\
\hline \multicolumn{5}{|c|}{ Irrigation interval } \\
\hline 7 days & 217.78 & 13.17 & 3.97 & 658.00 \\
\hline 10 days & 223.90 & 13.49 & 4.07 & 676.25 \\
\hline 15 days & 214.60 & 13.05 & 3.84 & 647.74 \\
\hline LSD at $5 \%$ & 0.64 & 0.05 & 0.03 & 0.76 \\
\hline
\end{tabular}

It is clear from the data presented in Fig. 1 that, all growth parameters were significantly increased in response to interaction of nitrogen fertilization in absence and presence of proline, plant distance and irrigation interval.
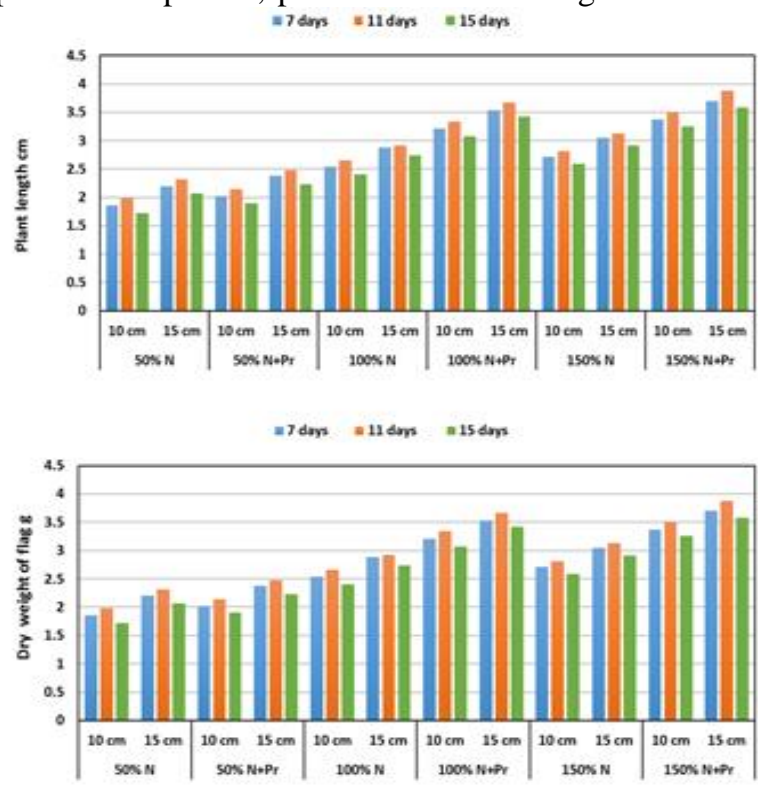

From the data found that highest mean values recorded with $150 \mathrm{~N}$-fertilization in presence of proline $+15 \mathrm{~cm}$ spacing and 11 days' intervals.
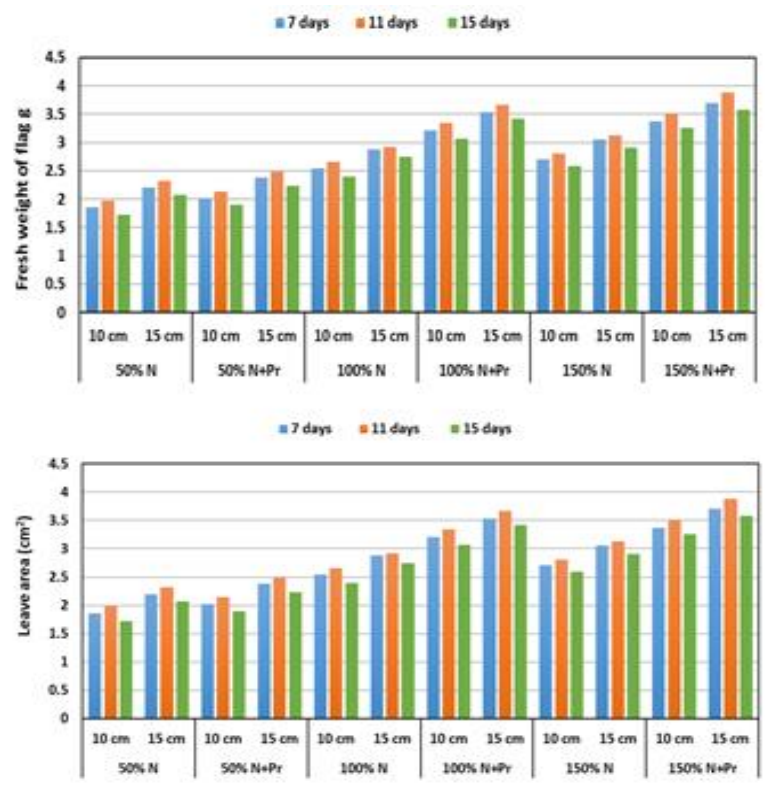

Fig . 1. Interaction effect of nitrogen fertilization in absence and presence of proline, plant distance and irrigation interval on growth parameters of maize plant. 


\section{Chlorophyll content:}

Presented data at Table 2 showed the effect of nitrogen fertilization levels and proline on chlorophyll content of maize leaves. Data reflected that with increasing nitrogen fertilization chlorophyll a, b and total chlorophyll increased in absence or presence of proline. The highest mean values of pigment recorded with using highest level of nitrogen fertilization and 50 ppm proline. This may be due to the role of nitrogen in increasing leaf area therefore chlorophyll content of leaves. This in turn caused an increase in photosynthetic levels (Hafez et al., 2014). In this respect, these results are in accordance with Hafez and Abdelaal 2015;Woldesenbet and Haileyesus 2016 and Ali and Anjum 2017). Thus, foliar applied proline enhanced the photosynthetic capacity of maize plant. There are number of reports which show that metabolic impairment is a major limitation to photosynthesis as Al-Shaheen and Soh (2016); Alamet al. (2016) and Baddouret al., 2017).

Chlorophyll content of maize leaves indicated at Table 2, were increased with increasing plant spacing and recorded high mean values at $15 \mathrm{~cm}$ in distance. This may be duo to that wide leaves increase the leaf chlorophyll level so, increment the phosynthetic process. Both wide leaf and high chlorophyll content led to a photosyntat process into dry materials and encourage the height development of the plant. This study supports Shafiet al. (2012) and Lihiang and Lumingkewas (2017).

Significant increase was happened in chlorophyll content (a, b and total) at the same Table, with increasing irrigation intervals up to 11 days then decreased at 15 days. This could be due to increasing

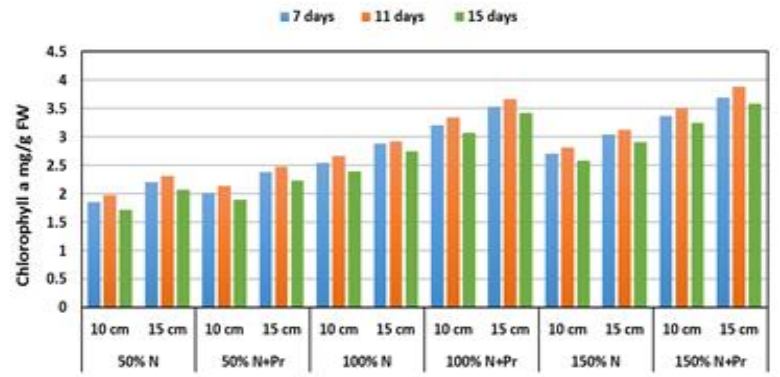

irrigation intervals led to decrease in leave are exhibits poor leaf growth and less photosynthesis.

The interactive effects of $\mathrm{N}$-fertilizer in absence and presence of proline, plant distance and irrigation interval on chlorophyll content ( $\mathrm{a}, \mathrm{b}$ and total) is indicated in Fig. 2, the results revealed that the highest mean values of previous parameters found with using $150 \mathrm{~N}$-fertilization in presence of proline $+15 \mathrm{~cm}$ spacing and 10 days' intervals.

Table 2. Individual application of nitrogen fertilization in absence and presence of proline, plant distance and irrigation interval on chlorophyll content of maize plant.

\begin{tabular}{|c|c|c|c|}
\hline Treatments & $\begin{array}{c}\text { Chlorophyll a } \\
\text { mg/g FW }\end{array}$ & $\begin{array}{c}\text { Chlorophyll b } \\
\text { mg/g FW }\end{array}$ & $\begin{array}{c}\text { Total } \\
\text { chlorophyll } \\
\text { mg/g FW }\end{array}$ \\
\hline \multicolumn{4}{|c|}{ Nitrogen and proline fertilization } \\
\hline $50 \% \mathrm{~N}$ & 0.714 & 0.448 & 1.162 \\
\hline $50 \% \mathrm{~N}+$ proline & 0.724 & 0.459 & 1.183 \\
\hline $100 \% \mathrm{~N}$ & 0.757 & 0.480 & 1.237 \\
\hline $\begin{array}{l}100 \% \mathrm{~N}+ \\
\text { proline }\end{array}$ & 0.801 & 0.512 & 1.313 \\
\hline $150 \% \mathrm{~N}$ & 0.768 & 0.488 & 1.256 \\
\hline $\begin{array}{l}150 \% \mathrm{~N}+ \\
\text { proline }\end{array}$ & 0.812 & 0.520 & 1.332 \\
\hline LSD at $5 \%$ & 0.002 & 0.005 & 0.006 \\
\hline \multicolumn{4}{|c|}{ Distance } \\
\hline $10 \mathrm{~cm}$ & 0.752 & 0.477 & 1.228 \\
\hline $15 \mathrm{~cm}$ & 0.774 & 0.492 & 1.266 \\
\hline LSD at $5 \%$ & 0.001 & 0.003 & 0.002 \\
\hline \multicolumn{4}{|c|}{ Irrigation interval } \\
\hline 7 days & 0.763 & 0.486 & 1.249 \\
\hline 10 days & 0.779 & 0.494 & 1.273 \\
\hline 15 days & 0.747 & 0.472 & 1.219 \\
\hline LSD at $5 \%$ & 0.002 & 0.003 & 0.003 \\
\hline
\end{tabular}

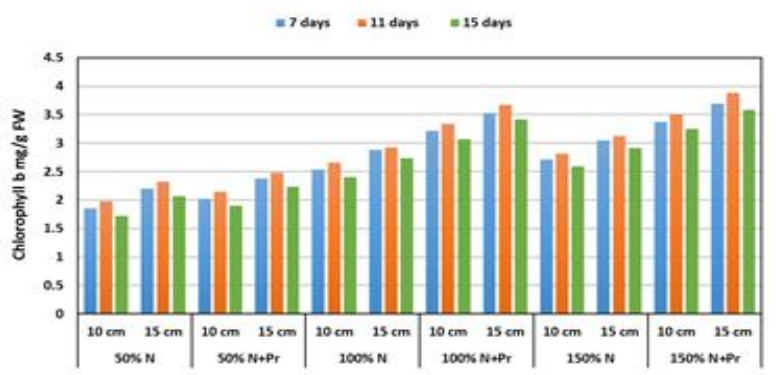

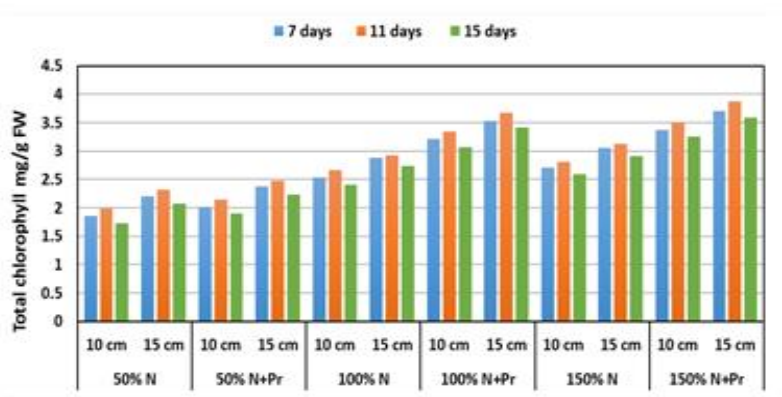

Fig . 2. Interaction effect of nitrogen fertilization in absence and presence of proline, plant distance and irrigation interval on chlorophyll content of maize plant.

\section{$\mathrm{N}, \mathrm{P}, \mathrm{K} \%$ and proline content $\mathrm{mg} / \mathrm{kg}$ :}

Table 3 illustrated the mean values of N, P, K \% and proline content of leaves as affected by $\mathrm{N}$-fertilization with proline in foliar way. It's clear from the data that application of nitrogen fertilization levels increased N, P, K
$\%$ and proline content in absence or presence of proline, and found that, highest values observed with application of $150 \% \mathrm{~N}+50 \mathrm{ppm}$ proline. This may be owed to the effective role of nitrogen in availability of nutrient in soil then its absorption by roots Similar results were obtained 
by Hafez and Abdelaal 2015; Woldesenbet and Haileyesus 2016 and Ali and Anjum 2017).Thus, application of exogenous proline could be an efficient means of decrease the adverse effects of irrigation interval on plants as has been observed in the present study (Alam et al. 2016 and Baddour et al., 2017).

Analysis of variance at the same Table, indicated that plant spacing had highly significant effect on $\mathrm{N}, \mathrm{P}$, $\mathrm{K} \%$ and proline content, and found that with increase distance to $15 \mathrm{~cm}, \mathrm{~N}, \mathrm{P}, \mathrm{K} \%$ and proline content were increased(Mahdi and Ismail 2015).

Respecting the nutritional status and proline content of maize plant as influenced by three irrigation intervals are shown in Table 3. The content of $\mathrm{N}, \mathrm{P}, \mathrm{K}$ and proline recorded higher values with irrigation at the shorter regime from 7 up to 11 days' interval then decreased at 15 days. This finding could be ascribing to the way that when soil moisture decreased, the nutrient mobility in the soil is towered and the rate of nutrients flow to root absorption zone decreased. In addition, the calculation of the gathered data reveals that the values of the above contents significantly varied within the irrigation treatments. Similar results were obtained by Abo-Marzoka et al., 2016; Abdou et al., 2017 and Majid et al., 2017.

A highly significant interaction between $\mathrm{N}$-fertilizer in absence and presence of proline, plant distance and irrigation intervals affected the concentration of $\mathrm{N}, \mathrm{P}$ and $\mathrm{K}$
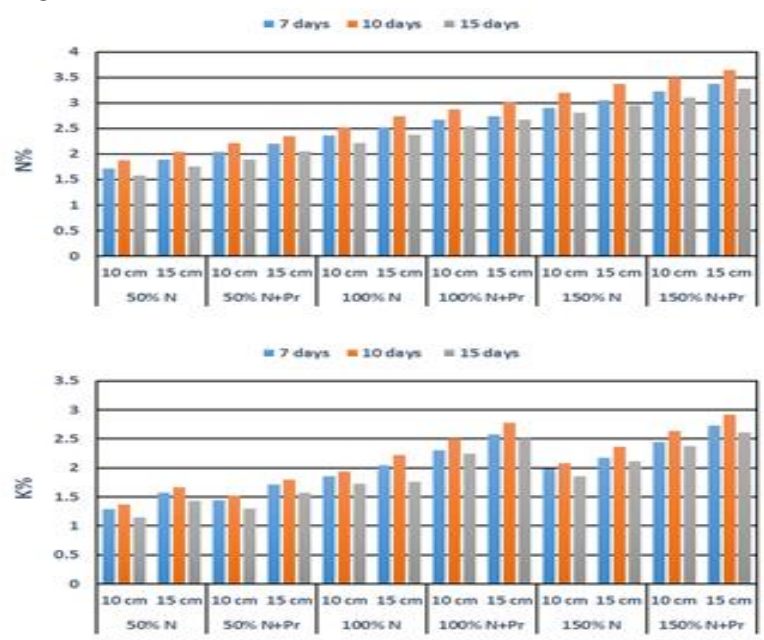

and proline content in leaves of maize plant. During the season the treatment of $150 \mathrm{~N}$-fertilization in presence of proline $+15 \mathrm{~cm}$ spacing and 10 days' intervals maintained significantly higher $\mathrm{N}, \mathrm{P}$ and $\mathrm{K}$ concentrations as well as proline content than other treatments as shown in Fig 3.

Table 3. Individual application of nitrogen fertilization in absence and presence of proline, plant distance and irrigation interval on $\mathrm{N}, \mathrm{P}, \mathrm{K} \%$ and proline content $\mathrm{mg} / \mathrm{kg}$ of maize plant.

\begin{tabular}{lcccc}
\hline Treatments & $\mathbf{N} \%$ & $\mathbf{P} \%$ & $\mathbf{K} \%$ & Proline $\mathbf{~ m g} / \mathbf{k g}$ \\
\hline \multicolumn{5}{c}{ Nitrogen } \\
$50 \% \mathrm{~N}$ & 1.81 & 0.226 & 1.41 & 10.90 \\
$50 \% \mathrm{~N}+$ proline & 2.12 & 0.238 & 1.56 & 14.57 \\
$100 \% \mathrm{~N}$ & 2.45 & 0.278 & 1.92 & 12.04 \\
$100 \% \mathrm{~N}+$ proline & 2.76 & 0.330 & 2.49 & 15.96 \\
$150 \% \mathrm{~N}$ & 3.05 & 0.290 & 2.10 & 13.37 \\
$150 \% \mathrm{~N}+$ proline & 3.35 & 0.343 & 2.62 & 17.50 \\
\hline LSD at 5\% & 0.03 & 0.002 & 0.06 & 0.12 \\
\hline \multicolumn{5}{c}{ Distance } \\
$10 \mathrm{~cm}$ & 2.51 & 0.271 & 1.89 & 13.66 \\
$15 \mathrm{~cm}$ & 2.67 & 0.297 & 2.14 & 14.45 \\
\hline LSD at 5\% & 0.01 & 0.001 & 0.03 & 0.04 \\
\hline \multicolumn{5}{c}{ Irrigation interval } \\
7 days & 2.56 & 0.285 & 2.01 & 14.02 \\
10 days & 2.78 & 0.297 & 2.15 & 13.51 \\
15 days & 2.43 & 0.270 & 1.89 & 14.64 \\
\hline LSD at 5\% & 0.01 & 0.001 & 0.04 & 0.06 \\
\hline
\end{tabular}
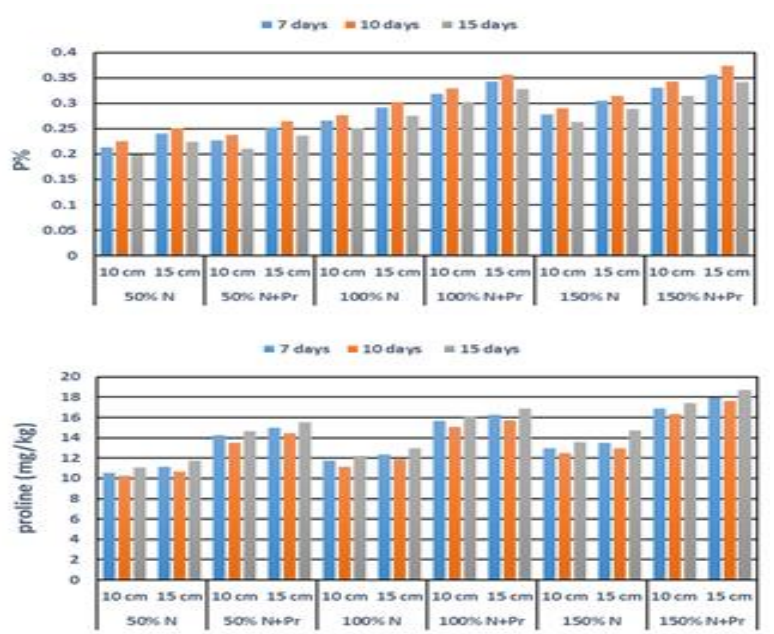

Fig 3. Interaction effect of nitrogen fertilization in absence and presence of proline, plant distance and irrigation interval on $\mathrm{N}, \mathrm{P}, \mathrm{K} \%$ and proline content of maize plant.
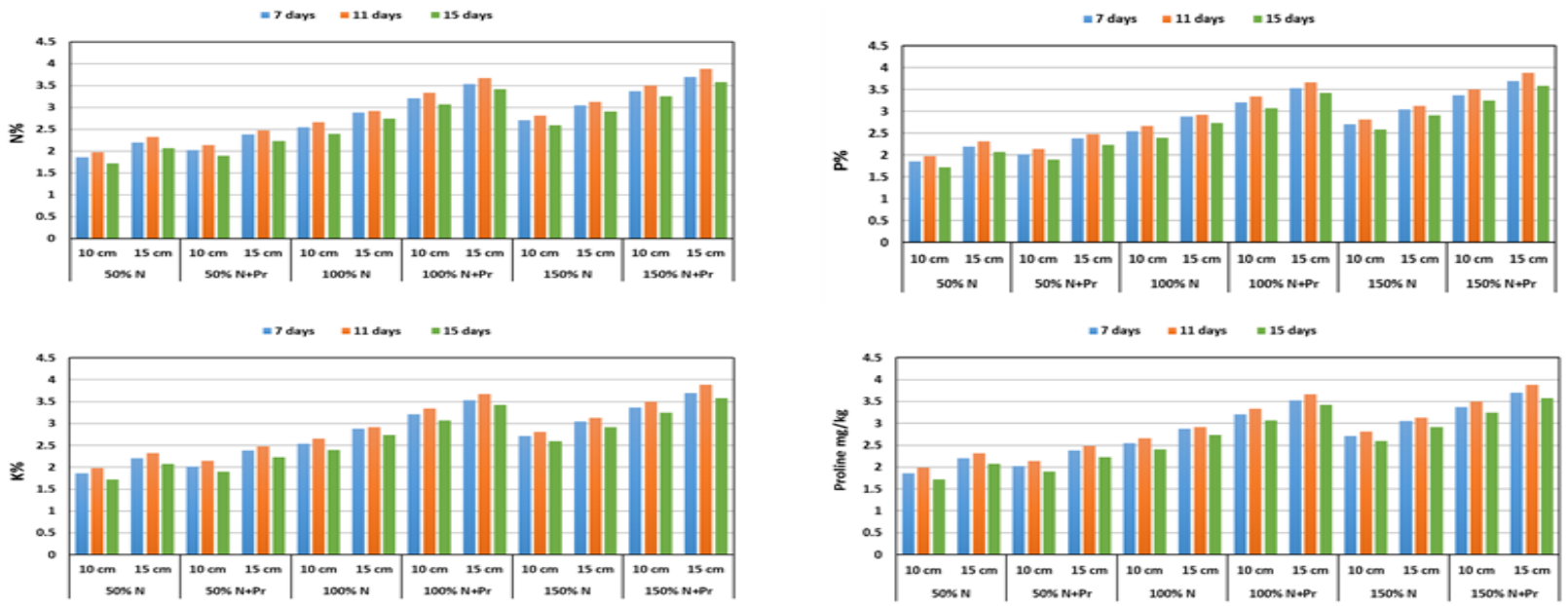

Fig 3. Interaction effect of nitrogen fertilization in absence and presence of proline, plant distance and irrigation interval on $\mathrm{N}, \mathrm{P}, \mathrm{K} \%$ and proline contebnt of maize plant. 


\section{Yield attributed:}

Concerning the effect of nitrogen fertilization and proline on yield and its component, data at Table 4 clearly showed that increase in nitrogen fertilization levels increased ear length, 1000-grain weight, total grain yield and straw yield in in absence or presence of proline. But found highest mean values of this parameters with application of $150 \% \mathrm{~N}$ from recommended presence of foliar $50 \mathrm{ppm}$ proline. These results might be attributed to the effect of nitrogen on the vigor vegetative growth and accumulation of photosynthesis assimilates which produce high number of grains/row and grains/ear and meristematic activity of maize plant and increasing yield attributes as final grain yield. These results are in accordance with (Hafez and Abdelaal 2015; Woldesenbet and Haileyesus 2016 and Ali and Anjum 2017). With some help from foliar application of proline to avoid stress by irrigation interval These results are similar to the findings of (Alam et al. 2016; Al-Shaheen and Soh 2016).

Yield attributes viz; ear length, 1000-grain weight, total grain yield and straw yield significantly influents by plant spacing present in Table 4. The maximum yield attributes were obtained with distance at $15 \mathrm{~cm}$ comparing with $10 \mathrm{~cm}$. This might be due to plant receive more sunlight by the canopy of plant and sufficient nutrient from the soil which results higher growth of plant and maximum yield attributes. The increase in number of grains in high plant space might be due to availability of more resources resulting in less competition. When the number of individuals per area is increased beyond the optimum plant density, there is a series of consequences that are detrimental to ear ontogeny that result in barrenness. Also could be due to more resources (nutrients +water) availability for relatively less number of plants which they utilized efficiently. Low grain weight in high plant population density was may be due to less photosynthesis availability for grain development on account of high interspecific competition which resulted in high rate of respiration and low rate of photosynthates as a result of enhanced mutual shading (Zamir et al., 2011). This result was in agreement with (Nand, 2015; Getaneh et al., 2016 and Lihiang and Lumingkewas 2017).

Concerning to the effect of the irrigation intervals, it was found as shown in Table 4 that irrigation intervals significantly enhanced the parameters ofear length, 1000grain weight, total grain yield and straw yield. The highest values of the parameters under investigation recorded up to the irrigation interval 11 days then decreased at 15 days. could be attributed to the fact that frequent irrigation would provide the crop with adequate moisture in the surface layer in which most of the maize roots exists, thus resulting in better crop nourishment and consequently higher yield. Also, the final grain yield depends upon the number of seeds/cob produced and extent to which the grains are filled. Increasing irrigation intervals up to 15 days will decrease the soil moisture availability in the root zone, which in turn decrease vegetative growth of corn plant and dry matter accumulation during filling of grains, as well as reducing nutrients absorption from soil. Similar results were reported by Abo-Marzoka et al., 2016; Abdou et al., 2017 and Majid et al., 2017.

Table 4. Individual application of nitrogen fertilization in absence and presence of proline, plant distance and irrigation interval on yield attributed of maize plant.

\begin{tabular}{|c|c|c|c|c|}
\hline Treatments & Ear length $\mathrm{cm}$ & 1000 grain weight $\mathrm{g}$ & Total grain yield ton/fed & Straw yield ton/fed \\
\hline \multicolumn{5}{|c|}{ Nitrogen and proline fertilization } \\
\hline $50 \% \mathrm{~N}$ & 15.61 & 27.00 & 2.65 & 3.72 \\
\hline $50 \% \mathrm{~N}+$ proline & 16.11 & 27.42 & 2.77 & 3.83 \\
\hline $100 \% \mathrm{~N}^{1}$ & 17.61 & 28.55 & 3.13 & 4.12 \\
\hline $100 \% \mathrm{~N}+$ proline & 19.64 & 29.97 & 3.65 & 4.58 \\
\hline $150 \% \mathrm{~N}$ & 18.11 & 28.99 & 3.24 & 4.25 \\
\hline $150 \% \mathrm{~N}+$ proline & 20.12 & 30.58 & 3.75 & 4.72 \\
\hline LSD at $5 \%$ & 0.10 & 0.07 & 0.05 & 0.05 \\
\hline \multicolumn{5}{|c|}{ Distance } \\
\hline $10 \mathrm{~cm}$ & 17.37 & 28.40 & 3.08 & 4.09 \\
\hline $15 \mathrm{~cm}$ & 18.36 & 29.11 & 3.32 & 4.31 \\
\hline LSD at $5 \%$ & 0.05 & 0.03 & 0.02 & 0.02 \\
\hline \multicolumn{5}{|c|}{ Irrigation interval } \\
\hline 7 days & 18.01 & 28.67 & 3.20 & 4.22 \\
\hline 10 days & 18.88 & 29.91 & 3.33 & 4.37 \\
\hline 15 days & 16.71 & 27.67 & 3.07 & 4.03 \\
\hline LSD at $5 \%$ & 0.05 & 0.03 & 0.03 & 0.04 \\
\hline
\end{tabular}

As for the interaction effect between the data under investigation as illustrated by Fig. 4, the results found that using $\mathrm{N}$-fertilization at the rate of $150 \%$ from recommended dose in presence of $50 \mathrm{mg} / \mathrm{kg}$ proline under
$15 \mathrm{~cm}$ plant spacing with 10 days irrigation interval realized the highest mean values of yield attributed of maize plant. 

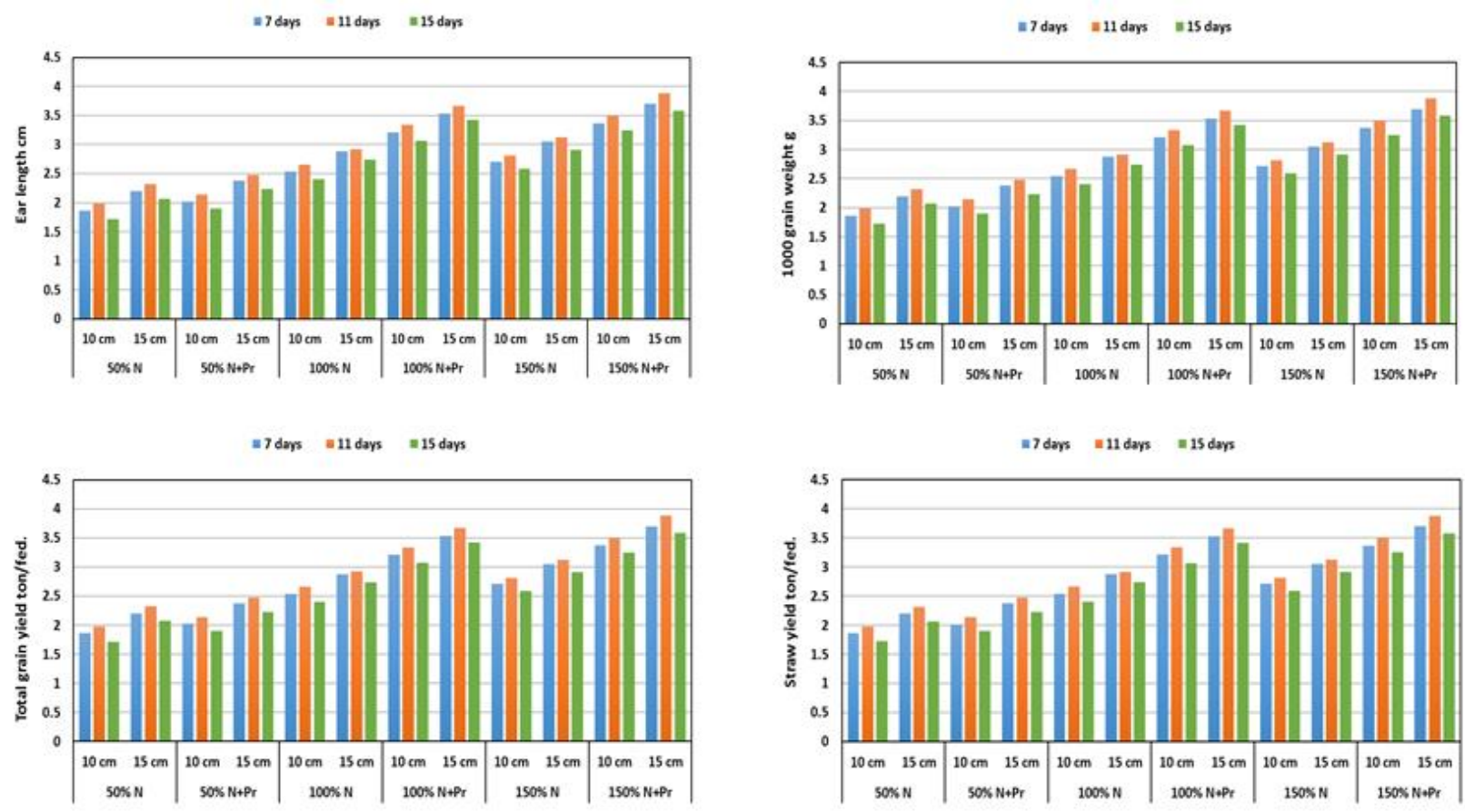

Fig . 4. Interaction effect of nitrogen fertilization in absence and presence of proline, plant distance and irrigation interval on yield attributed of maize plant.

\section{Grains quality:}

As shown from this investigation, data at Table 5 showed that using different rats of nitrogen fertilization in absence or presence of proline significantly effect on yield quality (crud protein, total carbohydrates, crud fiber and oil $\%$ ). The highest mean values of grain quality indicated with application of $150 \% \mathrm{~N}$ +proline. Increasing grain quality content of maize may be due to an increase in available $\mathrm{N}$-around root zone, which increase nitrogen supply to plant under high fertilization level of nitrogen, whereas, nitrogen plays an important role in the synthesis of protein. These findings concur with theresults obtained by (Hafez and Abdelaal 2015;Woldesenbet and Haileyesus 2016 and Ali and Anjum 2017). As for the effect of proline the same results are in agreement with the findings of (Abd El-Samad et al., 2010; Al-Shaheen and Soh 2016 and Baddour et al., 2017).

The crude protein, total carbohydrates, crud fiber and oil $\%$ were significantly affected by plant spacing as presented at Table 5. The maximum protein $(9.00 \%)$, total carbohydrates $(75.59 \%)$, crud fiber $(2.52 \%)$ and oil (2.95 $\%$ ) was observed with high plant spacing $15 \mathrm{~cm}$. This was attributed to the higher resources (nutrients +water) for grains which reflected on comparatively quality content in maize plant.Similar results were obtained by (Nand 2015 and Lihiang and Lumingkewas 2017).

Data at Table 5 indicated the effect of irrigation intervals on maize grain quality as crude protein, total carbohydrates, crud fiber and oil\%. The grain quality significantly affected by irrigation intervals from 7 up to 15 days. The highest mean values recorded at 11 days then decreased up to 15 days. This may be duo to reduce the available soil moisture in the root zone which in turn reduced yield attributed as well as quality of the grains Similar results were reported by Abo-Marzoka et al., 2016; Abdou et al., 2017 and Majid et al., 2017.

Table 5. Individual application of nitrogen fertilization in absence and presence of proline, plant distance and irrigation interval on quality of maize grains.

\begin{tabular}{|c|c|c|c|c|}
\hline Treatments & $\begin{array}{c}\text { C. protein } \\
\%\end{array}$ & $\begin{array}{c}\text { Total } \\
\text { carbohydrates } \\
\%\end{array}$ & $\begin{array}{c}\text { C. fiber } \\
\%\end{array}$ & Oil \% \\
\hline \multicolumn{5}{|c|}{ Nitrogen and proline fertilization } \\
\hline $50 \% \mathrm{~N}$ & 7.85 & 73.25 & 1.66 & 2.03 \\
\hline $50 \% \mathrm{~N}+$ proline & 8.18 & 73.68 & 1.82 & 2.19 \\
\hline $100 \% \mathrm{~N}$ & 8.64 & 74.94 & 2.30 & 2.69 \\
\hline $100 \% \mathrm{~N}+$ proline & 9.48 & 76.67 & 2.92 & 3.37 \\
\hline $150 \% \mathrm{~N}$ & 8.85 & 75.43 & 2.42 & 2.87 \\
\hline $150 \% \mathrm{~N}+$ proline & 9.68 & 77.06 & 3.08 & 3.55 \\
\hline LSD at $5 \%$ & 0.15 & 0.11 & 0.03 & 0.02 \\
\hline \multicolumn{5}{|c|}{ Distance } \\
\hline $10 \mathrm{~cm}$ & 8.56 & 74.76 & 2.21 & 2.62 \\
\hline $15 \mathrm{~cm}$ & 9.00 & 75.59 & 2.52 & 2.95 \\
\hline LSD at $5 \%$ & 0.10 & 0.06 & 0.03 & 0.02 \\
\hline \multicolumn{5}{|c|}{ Irrigation interval } \\
\hline 7 days & 8.77 & 75.18 & 2.36 & 2.79 \\
\hline 10 days & 9.05 & 76.28 & 2.20 & 2.90 \\
\hline 15 days & 8.52 & 74.06 & 2.54 & 2.66 \\
\hline LSD at $5 \%$ & 0.09 & 0.07 & 0.02 & 0.02 \\
\hline
\end{tabular}

Interaction effect between treatments under investigation significantly increased crude protein, total carbohydrates, crud fiber and oil\%as shownin Fig. 5. The highest values recorded with using $150 \%$ Nfertilization $+50 \mathrm{mg} / \mathrm{kgp}$ roline under $15 \mathrm{~cm}$ plant spacing with 10 days' irrigation intervals. 

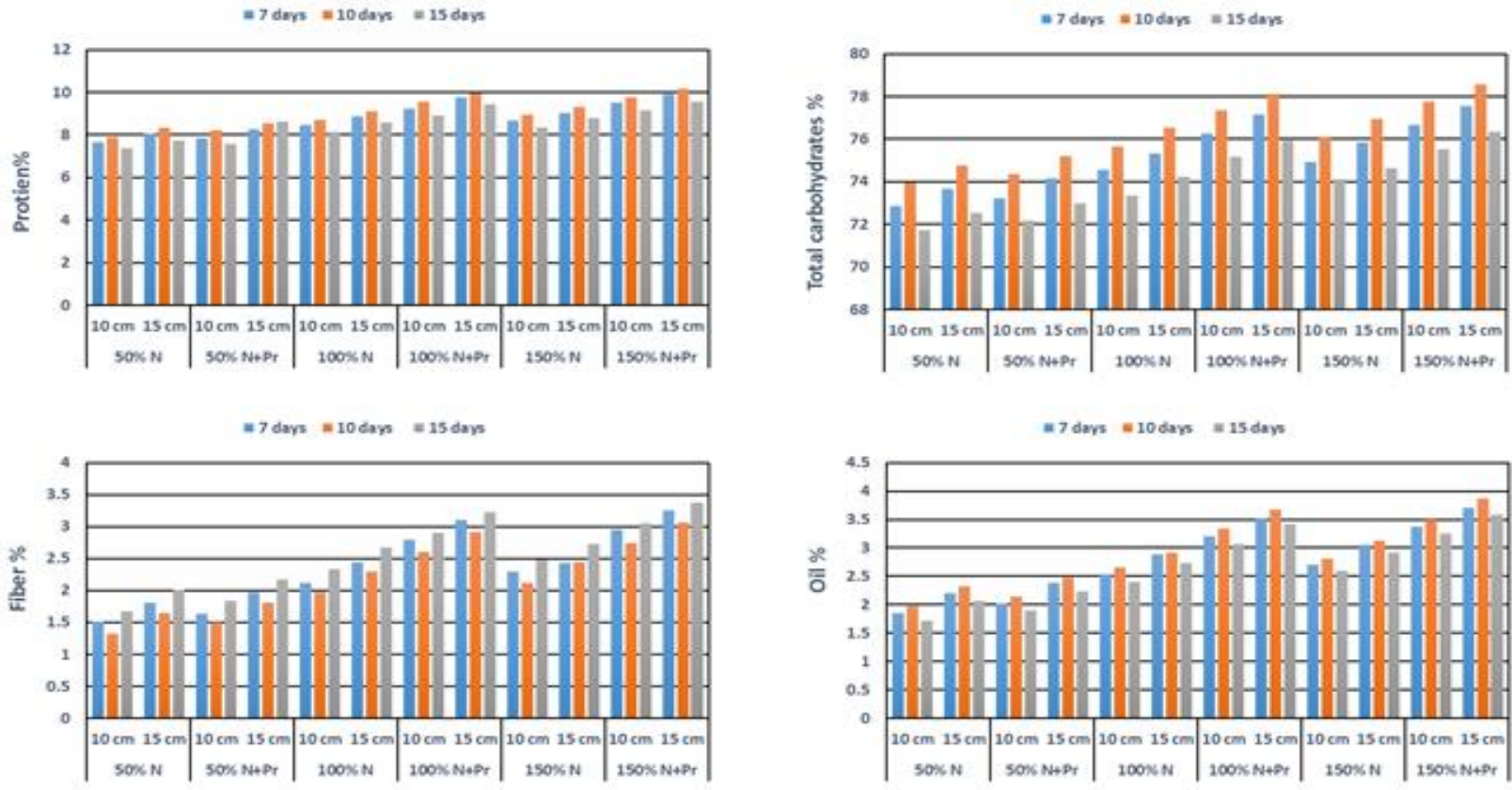

Fig . 5. Interaction effect of nitrogen fertilization in absence and presence of proline, plant distance and irrigation interval on maize graine quality.
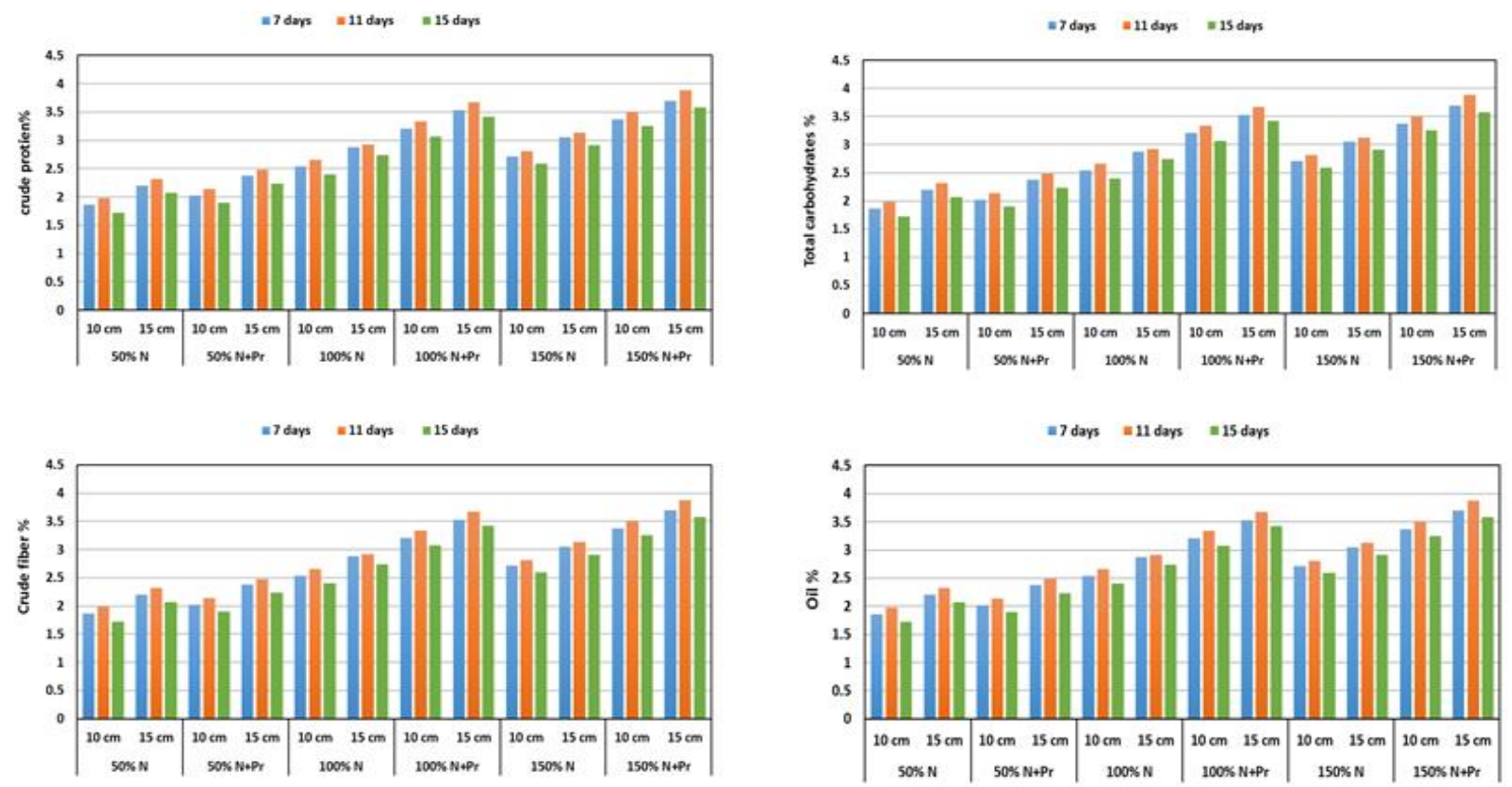

Fig. 5. Interaction effect of nitrogen fertilization in absence and presence of proline, plant distance and irrigation interval on maize graine quality.

\section{CONCLUSION}

From the findings of the present research it can be concluded that when the maize efficiently served, it gave high grain yield and good quality. Throughout the growth period the increased nitrogen level in presence of proline was beneficial for maintaining and improving the green and dry matter fodder maize yield with wide space between plants under different irrigation intervals. Therefore, it is recommended that $150 \%$ nitrogen applications from recommended dose and foliar application of $50 \mathrm{mg} / \mathrm{kgproline}$ with $15 \mathrm{~cm}$ plant distance under 10 days' interval irrigation are the most economical strategy for obtaining best quality grain maize yield.

\section{REFERENCES}

A.O.A.C. (2000) "Official methods of Analysis" Twelfth Ed. Published by the Association of Official Analytical chemists, Benjamin, France line station, Washington. Dc.

Abd El-Samad, H. M., M. A. K. Shaddad and N. Barakat (2010). The role of amino acids in improvement in salt tolerance of crop plants. J. Stress Physiology \&Biochem., 6 (3): 25-37. 
Abdel-Maksoud, H. H.; M. R. K. Ashry and K. M. R. Youssef (2008). Maize yield and water relations under different irrigation and plant density treatments. J. Agric. Sci. Mans. Univ., 33(5): 39293941.

Abdou, S. M. M.; A. R. Ahmed and M. A. Bayoumi (2017). interactive effect of nitrogen fertilizer forms, irrigation intervals and soil conditioners on maize productivity grown on clay loam soil. J. Soil Sci. and Agric. Eng., Mans. Univ., 8 (11): 593-603.

Abo-Marzoka, E. A.; R. F. Y. El-Mantawy and I. M.Soltan (2016). Effect of irrigation intervals and foliar spray with salicylic and ascorbic acids on maize. J. Agric. Res. Kafr El-Sheikh Univ., 42 (4): 506-518.

Agrilasa, (2002). Handbook on feeds and plant analyses. AGRILASA, Pretoria. South Africa.

Alam, R., D. K. Das, M. R. Islam, Y. Murata and M. A. Hoque (2016). Exogenous proline enhances nutrient uptake and confers tolerance to salt stress in maize (Zea mays L.). Progressive Agric., 27 (4): 409-417.

Ali, A.; A. Malik, M. A. Choudhry, M. Khaliq and M. Rafique (1999). Effect of various doses of nitrogen on the growth, yield and protein content of two maize genotypes. Pak. J. Biol. Sci., 2(3): 889-89.

Ali, N. and M. M. Anjum (2017). Effect of different nitrogen rates on growth, yield and quality of maize. Middle East J. Agric. Res., 6(1): 107 - 112.

Ali, Q.; F. Anwar, M. Ashraf, N. Saari and R. Perveen (2013). Ameliorating effects of exogenously applied proline on seed composition, seed oil quality and oil antioxidant activity of maize (Zea mays L.) under drought stress. Int. J. Mol. Sci., 14: 818-835.

Alimohammadi, M.; M. Yousefi and P. Zandi (2011). Impact of nitrogen rates on growth and yield attributes of sweet corn grown under different phosphorus levels. J. Am. Sci.,n 7(10):201-206.

Al-Shaheen, M. R. and A. Soh (2016). Effect of proline and Gibberellic Acid on the qualities and qualitative of Corn (Zea maize L.) under the influence of different levels of the water stress. Intl J. Scientific and Res. Pub., 6 (5):752-756.

Baddour, A. G., Eman M. Rashwan and T. A. ElSharkawy (2017). Effect of Organic Manure, Antioxidant and Proline on Corn (Zea mays L.) Grown under Saline Conditions. Env. Biodiv. Soil Security, 1: 203- 217.

Bamuaafa, M. S. S. (2012). Effect of irrigation and nitrogen fertilization on yield and quality of corn. Ph.D. Thesis, Agron. Dep. Fac., Agric., Assiut Univ., Egypt.

Boloyi, C. (2014). Do row spacing and plant density influence maize productivity under reduced tillage. Arc-grain Corps Institute. www.grainsa.coizaldorow-spacing and -Plant-Density Influence- Maize Productivity. Retrieved $23^{\text {rd }}$ Feb. 2015.

Carmo, M. S.; S. C. S. Cruz, E. J. Souza, L. F. C. Campos and C. G. Machado (2012). Doses e fontes de nitrogênio no desenvolvimento e produtividade da cultura de milhodoce (Zea maysconvar. Saccharata var. Rugosa). Biosci. J. 28: 223-231.
El-Beltagy, A.T., and A.F. Abo-Hadeed. 2008. The main pillars of the National Program for maximizing the water-use efficiency in the old land. $30 \mathrm{p}$. The Research and Development Council. Ministry of Agriculture and Land Reclamation (MOALR), Giza, Egypt (in Arabic).

El-Tantawy, M. M.; S. A. Ouda and F. A. F. Khalil (2007). Irrigation scheduling for maize grown under Middle Egypt conditions. Res. J. Agric. and Biol. Sci.,3(5): 456-462.

Futlless, K. N.; Y. M. Kwaga and S. M. Aberakwa (2010). Effect of spacing on the performance of extra early yellow maize (Zea mays L.) Variety Tzesr-Y in Mubi Adamawa State. J. Am. Sci. 6(10):629-633.

Gavrilenko V. F. and T. V. Zigalova (2003). The Laboratory Manual for the Photosynthesis. Academia, Moscow. 256 cтр. (in Russian).

Gerpacio, V. R. and P. L. Pingali (2007). Tropical and subtropical maize in Asia: production systems, constraints and research priorities. CIMMYT, Mexico, ISBN: 978-970-648-155-9. p. 93.

Getaneh; L.; K. Belete and T. Tana (2016). Growth and Productivity of Maize (Zea mays L.) as Influenced by Inter- and Intra-Row Spacing in Kombolcha, Eastern Ethiopia. J. Biology, Agric. and Healthcare, 6 (13): 90-101.

Gomez, K. A. and A. A. Gomez (1984). "Statistical Procedures for Agricultural Research". John Wiley and Sons, Inc., New York.pp:680.

Hafez, E. M. and Kh. A. A. Abdelaal (2015). Impact of nitrogen fertilization levels on morphophysiological characters and yield quality of some maize hybrids (Zea mays L.). Egypt. J. Agron., 37 (1): $35-48$.

Hafez, E. M.; A. Y. Ragab and T. Kobata (2014). Wateruse efficiency and ammonium-N source applied of wheat under irrigated and desiccated conditions. Intl. J. Plant \& Soil Sci., 3(10): 1302-1316.

Ibeawuchi, I. I.; E. Matthews-Njoku, M. O. Ofor, C. P. Anyanwu and V. N. Onyia (2008). Plant Spacing, Dry Matter Accumulation and Yield of Local and Improved Maize Cultivars. J. American Sci., 4(1): 11-20.

Ibrahim, S. A. and H. Kandil (2007). Growth, yield and chemical constituents of corn (Zea mays L.) as affected by nitrogen and phosphors fertilization under different irrigation intervals. J. Appl. Sci. Res., 3(10): 1112-1120.

Lihiang, A. and S. Lumingkewas (2017). The effect of planting distance and number of seeds on growth, production, and quality of local maize (Zea mays L.), Manado Kuning. Intl. J. App. Chem., 13 (3): 673-690.

Mahdi, A. H. A. and S. K. A. Ismail (2015). Maize productivity as affected by plant density and nitrogen fertilizer. Intl. J. Curr. Microbiol. App. Sci., 4(6): 870-877.

Majid, M. A.; M. S. Islam, A. EL Sabagh, M. K. Hasan, C. Barutcular, D. Ratnasekera and M. S. Islam (2017). Evaluation of growth and yield traits in corn under irrigation regimes in sub-tropical climate. $\mathrm{J}$. Experimental Biol. and Agric. Sci., 5 (2):143.150. 
Marin, J. A.; P. Andreu, A. Carrasco and A. Arbeloa (2010). Determination of proline concentration, an abiotic stress marker, in root exudates of excised root cultures of fruit tree rootstocks under salt stress. Revue Des RégionsArides - NuméroSpécial. 24 (1): 722-727.

Meister, A. (2012). Biochemistry of the amino acids, Elsevier.

Mekdad, A. A. A. (2015). Sugar beet productivity as affected by nitrogen fertilizer and foliar spraying with boron. Int. J. Curr. Microbiol. App. Sci., 4(4): 181-196.

Mertens, D., (2005). AOAC official method 922.02. Plants preparation of laboratuary sample. Official methods of analysis, $18^{\text {th }}$ edn. North Frederick Avenue, Gaitherburg, Maryland, pp.1-2

Nand, V. (2015). Effect of spacing and fertility levels on protein content and yield of hybrid and composite maize (Zea mays L.) grown in rabi season. J. Agric. and Veterinary Sci., 8 (9): 26-31.

Reddy, A. R.; K. V. Chaitanya and M. Vivekanandan (2004). Drought- induced responses of photosynthesis and antioxidant metabolism in higher plants. J. Plant Physiol., 161: 1189-202.

Reeuwijk, L. P. (2002). Procedures For Soil Analysis. Inter. Soil Ref. and Info. Center. Food and Agric. Organization of the United Nations.

Reza, R. S. A. and R. Mehdi (2002). The examination of the effect of irrigation interval and nitrogen amount on yield and yield components of maize (Zea mays L. cv. Single cross 704) in Mazandaran province. Intel. J. of Biol., 4 (2): 70-78.

Saadat, S. A.; H. R. Miri and B. Haghighi (2010). Study effect of density on yield and yield components in corn hybrids. Proceeding of $11^{\text {th }}$ Iranian Crop Science Congress, 24 (26): 2914-2917.
Shafi, M.; J. Bakht, S. Ali, M. A. Khan and M. Sharif (2012). Effect of planting density on phenology, growth and yield of maize (Zea mays L.). Pak. J. Bot. 44 (2): 691:696.

Sharaan, A. N.; K. M. R. Yousef, F. S. Abd El-Samei and H. M. Ibrahim (2002). Maize yield and water relations under combinations of tillage systems and irrigation intervals. Proc. The $2^{\text {nd }}$ Conf. of Sustainable Agric. Dev., Fayoum Fac. Of Agric. Egypt.,:31642.

Shrestha, J.; A. Chaudhary and D. Pokhrel (2018). Application of nitrogen fertilizer in maize in Southern Asia: a review. Peruvian J. Agronomy, 2 (2): $22-26$.

Shumaila, G. and M. Safdar (2009). Proximate Composition and Mineral Analysis of Cinnamon. Pakistan J. Nutr., 8 (9): 1456-1460.

Tahmasbi, A. and M. H. Mohasel (2009). The effect of density and planting pattern on yield and yield components of two corn hybrids (KSC700 and KSC704) in Kurdistan. J. Iran Agron. Res., 7(1): 105-113.

Tarighaleslami, M.; R. Zarghami, M. M. A. Boojar and M. Oveysi (2012). Effects of drought stress and different nitrogen levels on morphological traits of proline in leaf and protein of corn seed (Zea mays L.). American-Eurasian J. Agric.l and Environ. Sci., 12: 49-56.

Woldesenbet, M. and A. Haileyesus (2016). Effect of nitrogen fertilizer on growth, yield and yield components of maize (Zea mays 1.) In Decha district, southwestern Ethiopia. Intl. J. Res. GRANTHAALAYAH, 4 (2): 95-100.

Zamir, M. S. I.; A. H. Ahmad, H. M. R. Javeed and T. Latif (2011). Growth and yield behaviour of two maize hybrids (Zea mays L.) towards different plant spacing. CercetariAgronomice in Moldova. 14 (2):33-40.

\footnotetext{
تأثير التسميد النيتروجيني و البرولين و المسافة بين النباتات والري علي نمو الذره

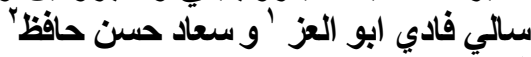

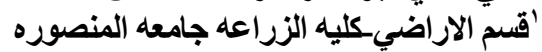

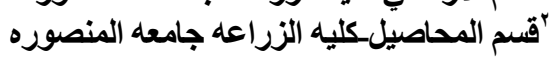

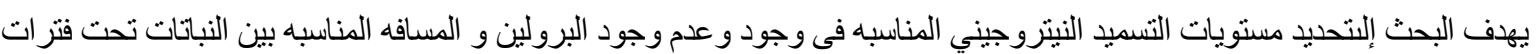

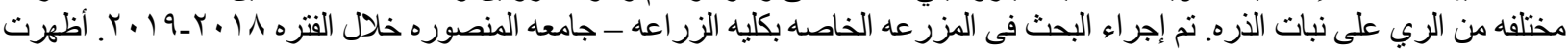

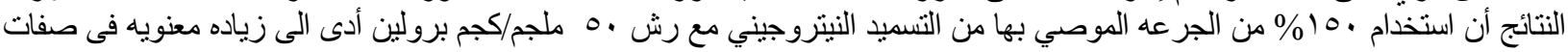

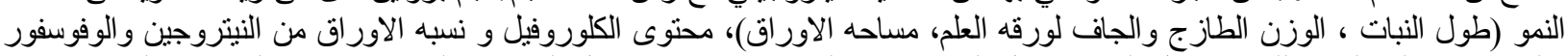

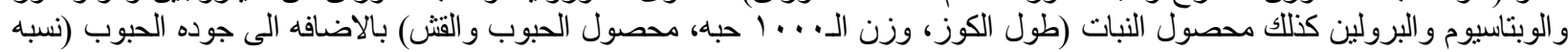

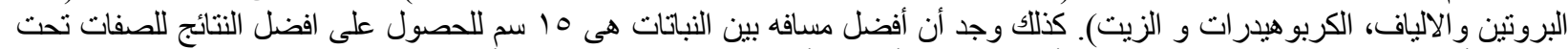

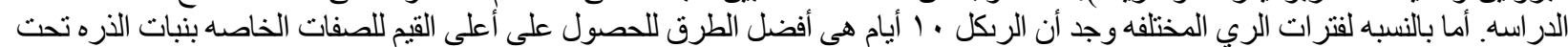

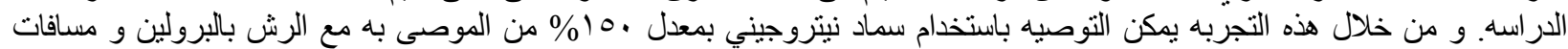

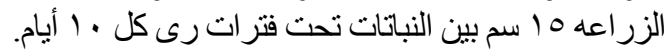

